\title{
Marketing In America's Large Protestant Churches
}

Cynthia M. Newman, (Email: cnewman@ rider.edu), Rider University

Paul G. Benchener, (Email: benchener@rider.edu), Rider University

\begin{abstract}
The current study assesses, from a quantitative perspective, the extent to which marketing and planning are being effectively used by large, Protestant churches to meet their goals. Even though the debate over whether religious organizations should apply business world concepts continues, the use of management and marketing practices from business in churches, particularly large churches, does occur.
\end{abstract}

\section{INTRODUCTION}

\begin{abstract}
hile there continues to be significant debate about the efficacy of using business tools and models within the church context, the use is occurring, especially among large churches. In an environment where churches are striving to grow attendance and to make the most effective use of limited resources, the areas of marketing and planning offer means by which these organizational goals can be accomplished. Much of the existing discussion about the use of marketing and planning by churches is anecdotal in form or, at best, based on case studies. Therefore, the purpose of the current study is to assess, from a quantitative perspective, the extent to which marketing and planning are being effectively used by large, Protestant churches to meet their goals.
\end{abstract}

\section{THE DEBATE AND CURRENT STATUS}

While many marketing concepts may be as old as the Bible, and some may have been used during the time of the New Testament early church in the Bible, significant debate continues about their use for religious organizations today. The current research into the use of marketing in religious organizations did not go back as far as the New Testament; however, we found that over 50 years ago marketing techniques within religious organizations were recommended (Culliton, 1959). In addition, "The Man who Brought Marketing to the Church," George Barna (1988), found that the fastest growing churches are those which have learned to effectively apply marketing techniques. But squarely on the other side of the debate are the critics of marketing use by religious organizations. These critics assert that fast growing churches are not really in the religion business but in the selfhelp trade and that they represent the "Disneyfication" of religion ("Jesus, CEO," 2005). Is this debate simply theoretical? Or does it have some real- world significance?

Perhaps a look at the question from three points of view about the argument (for, against and an attempt at a reconciliated view) would provide an answer. Those in favor of the use of marketing in churches and other religious organizations report that many pastors are supportive. For example, Cutler (1991) says that "it appears that the clergy, in general, are quite receptive to marketing practices although they might prefer not to use the term 'selling' or 'marketing'." Also, many in this group would agree with Kotler and Levy (1969): "The choice...is not whether to market or not to market, for no organization can avoid marketing...the choice is whether to do it well or poorly" (Webb, Joseph, Schimmel, Moberg, 1998, p. 3).

Those who are against marketing within religious organizations are diverse and vocal with emotionallycharged views. Part of this group is the public. Several studies indicate the public is not as favorably inclined to marketing by churches as are the pastors. Strongly-worded arguments such as "Marketing and religion are generally 
considered to be as compatible as oil and water" are common (Kinsman, 2002, para.1). Others say, "Today's churches compete against churches and synagogues compete against synagogues for members. Their competition is done through marketing... The increase in numbers seems to be the only measure legitimizing the use of marketing as a tool for growth... [and] their purpose in gaining new members is an automatic revenue increase- the real reason behind all marketing...God didn't need Madison Avenue to attract members" (Coke, 2004, para.1). In a 1994 article, Bruce Wrenn discusses six major criticisms of religious marketing:

1. It wastes money

2. It is manipulative

3. It opposes the spirit of leadership

4. It strips the sacred significance from religion

5. It is beneficial only if one has a lot of money to spend

6. It is at odds with biblical views. (Wrenn, 1993)

Others simply assert marketing places the focus in the wrong place: "Judaism and Christianity place a high premium on humility. Advertising calls attention and implies pride" (Marty, 1987, p.56).

The third position is the attempt at a reconciled view - a means to mediate between the two other divergent views. Those who hold this view often agree that confusing marketing with advertising, sales or even coercion is behind the problem. Bruce Wrenn (1993) writes that the way in which the concept of marketing is understood by a church is important. If it is understood as "marketing the church," that concept may not be acceptable; however, if it is understood as "being responsive to people's needs" (including current members as well as a well-defined segment of society) that may well be acceptable since that is "at the heart of why churches exist" (p. 241). The key point for this "reconciling group" is to keep the core theology intact while fostering openness to different avenues of delivery to satisfy the needs of the community. When all of the viewpoints of whether "to market or not to market" in religious organizations are analyzed, it is clear that religious marketing remains an unresolved real-world issue.

Regardless of the debate, however, churches and other religious organizations are using marketing techniques. An article in 2001 reports, "Churches and ministries have boosted their marketing expenditures by 50 percent in the past five to 10 years" (Stuart, 2001, para.3). So it would seem that some religious organizations realize they need business and marketing skills (Cutler and Winans, 1999).

What types of religious organizations are using marketing strategies and tactics? Studies actually show the practices are quite widespread. For example, the current analysis of the literature shows that while Christian groups are the leader in using the Web (discussed later in this article), other religions, such as Islamic, Hindu and Buddhism, are also involved (Belsie, 1995).

What tactics are being implemented? Brochure, radio, direct mail, postcard and sponsorship (event marketing) together with media coverage and on-site signage are being utilized. In short, religious organizations are employing all of the tactics and strategies of ordinary marketing and advertising (Cutler and Winans, 1999). Print media and personal contacts are the tools used most frequently by church pastors (Webb et al, 1998). Further research demonstrates that the best marketing communication techniques, per both clergy and the general public, are the yellow pages for non personal communication and classes to introduce new people to the religious organization for personal communication (McDaniel, 1986).

Market segmentation and the analysis of potential target markets are utilized. "Now churches of all types, as never before, are using sophisticated secular methods to draw people. Some are turning to computer-assisted demographic research...to target specific groups" (Housewright, 1995, p.22). For example, Dr. Milfred Minatrea says, "Before a new Baptist church is started in Dallas County [Dallas, TX], a study is done that includes a demographic profile of the area....We're not trying to exclude any group, but to ensure we're reaching every group" (Housewright, 1995, p.22). At Marble Collegiate Church in New York City a senior minister reports "there are ministries for senior citizens; young singles; older singles; gays and lesbians; entrepreneurs; artists, actors, and writers; men; women; children; and people who love singing gospel music, to name a few" (Wellner, 2001, p.50). 
The Southern Baptist denomination is using target marketing in their advertising campaigns. They have targeted four different demographic groups: Generation X, baby boomers, urban poor and working professionals (Miller, 1998). And not only Christian churches are involved in segmentation and target marketing. "At Makor, a New York City religious center charged with helping young Jewish adults reconnect with their faith, Rabbi David Gedzelman, creative director, conducted 20 focus groups with his 'target market"' (Wellner, 2001, p. 53).

Advertising is a major part of many religious organizations' marketing efforts. John Follis, president of Follis Advertising in New York who worked with Marble Collegiate Church, explains, "Imagine advertising a product that 1) does everything; 2) costs nothing; 3 ) is available 24/7; and 4) comes with a lifetime warranty...To the uninitiated, it may seem strange to market a church like a box of Kellogg's Frosted Mini-Wheats. Well, obviously, you don't market a church like a box of Frosted Mini-Wheats. How then? By selling spirituality. More specifically, by selling God....Despite the tough sell and tiny budget, membership is up more than 30 percent, traffic to the Web site has tripled and overall awareness is remarkably high" (Follis, 2001, p.14).

Mormons are the leading religious advertiser on a national level. Baptists are the leaders at the local level (Moncrief, Lamb, Hart, Hile, 1986). Other religious advertisers include the United Methodist Church, which reports that a \$20 million five-year advertising campaign boosted their attendance, and Roman Catholic nuns and priests have turned to advertising to increase their numbers. Similarly, the Evangelical Lutheran Church of America hired an ad agency and spent approximately $\$ 3$ million to create two advertising spots on television (Miller, 1998). And, finally, the Church of Scientology and the Church of England have been running competing religious ads in Britain since 1996 (Barrett, 1996).

More and more religious organizations, particularly churches, are using outdoor advertising, especially billboards, to spread their message. An anonymous donor gave more than $\$ 100,000$ for a billboard campaign that includes ads such as: "Let's meet at my house Sunday before the game - God"; "Love the wedding, invite me to the marriage" and "I meant that 'Love Thy Neighbor' thing" (Veenker, 1999, para.3).

Electronics in general, the Internet and the Web in particular, are just beginning to be used by religious organizations. "There's a new audience that has grown up on electronics. With the advent of the Internet and digital technology, there are unprecedented methods to go out and reach the entire world now with a faith-based message that was, just 20 years ago, not available" (Stuart, 2001, pg.1). One view expressed is that the use of electronics in religious marketing is changing the way religion is disseminated, much the same way as the printing press did centuries ago (Parker, 2001).

Additional marketing tactics are used by religious organizations. A review of the literature found significant use of market research, church-related retailing and even the use of the time-tested information center. Through market research, the UCC [United Church of Christ] found that many Americans who do not attend church felt alienated from church in general. So, it developed themes of inclusivity and acceptance for its marketing activities (Duin, 2005). Church-related retailing is used by many church denominations, particularly the Episcopal churches, while the Mennonites do most of the marketing of their denomination through their information center in Lancaster, PA (Quinn, 2001).

Market-savvy individuals have begun to see the power of marketing with religious organizations as well. Recently, there have been two excellent examples of this technique: Mel Gibson's movie, The Passion of the Christ, which reached blockbuster status, and Rick Warren's book, The Purpose Driven Life, which became an international best seller. But these two examples, of course, simply intensified the debate over mixing sophisticated advertising with religion. While the financial results and wide distribution were outstanding, the debate about appropriateness continues among religious organizations.

Are all religions involved in marketing? Not according to Rabbi Kenneth Roseman, who says that some religions, lacking Christianity's history of outreach, have not marketing themselves. "We're basically not an evangelistic people," says Roseman (Housewright, 1995, p. 22). 
For what purposes have these strategies and tactics been used? Some have implemented marketing strategies in order to increase attendance at church. Others have done so in order to promote attention to their specific group, while others hope to raise funds. Finally, some of the religious groups are engaged in marketing to understand the full scope (beyond the church down the street) of their competition.

What have the outcomes been from using these strategies and tactics? Mixing sophisticated advertising with sacred purposes has generated some impressive results. For one thing, focusing on attracting young adults has generated some significant increases: "Hillcrest's congregation [North Dallas] is 5,000 members strong and has grown by 25 percent over the last five years ... with much of the growth coming from the young adult segment. Marble Collegiate's [New York] Web site traffic has increased by 30 percent since its ad campaign launched, and the church has had its highest attendance in more than 30 years. At Makor [New York], since the center opened in October of 1999, 22,000 young adults have been to the center and signed up for Makor's mailing list" (Wellner, 2001, p. 55). The implementation of marketing concepts aided The Willow Creek Community Church congregation in Chicago to grow from 125 worshippers to 16,000 (Burger, 1997). The United Church of Christ (1.3-millionmembers strong and America's most liberal Protestant denomination) saw the amount of hits on its Web site increase over 500\% in one year (from 950,000 to 5 million) after a thirty second $\$ 1.5$ million TV ad that showed two muscular male bouncers blocking a church entrance. Their ad? "Jesus didn't turn people away. Neither do we" (Duin, 2005, para.3).

\section{SAMPLE AND METHODOLOGY}

The population of interest for this study was church leaders from various mega Protestant churches across the United States. A random sample of 500 mega church leaders from throughout the United States was selected from a population list of 1,000. The mailing list was provided by MCH Mailings. A mega church is defined as a religious organization with 2,000 or more members. This segment of US churches was selected for the present study because it was thought that larger churches were more likely to have the interest and the resources, both financial and human, to engage in a fully developed marketing process than smaller churches.

Surveys were sent to the lead pastor or minister with the instruction to either complete the survey or direct the survey to the appropriate person within the church organization. The survey was two pages in length and consisted of 27 questions regarding the church's use of various planning and marketing techniques as well as whether these churches set themselves apart from other churches in their geographic area. The survey objectives were to identify what marketing techniques are being used by churches, what assumptions regarding segmentation and positioning are being made, and whether competitive analyses are being conducted. The survey also sought demographic information about the respondent and his or her church.

In order to improve the response rate, a second reminder mailing was sent two weeks following the original mailing and two weeks before the due date. One survey was returned due to an incorrect address and 61 completed surveys were received, yielding a $12.2 \%$ response rate.

\section{PRESENTATION AND DISCUSSION OF RESULTS}

\section{Profile Of Respondents}

As would be expected given the nature of the mailing list used for survey distribution, the most common position held by the respondents was senior pastor or minister $(39.3 \%, 24)$. The next most common was administrator or executive director $(26.2 \%, 15)$; no other titles were held by more than 5 respondents. The respondents reported an average of 20 years of employment at a church or other religious organization with the average tenure in their current position being just under nine years.

In terms of areas of direct responsibility, nearly all the respondents listed areas related to preaching, teaching and care. Beyond these, more than one-third of the respondents $(36.0 \%, 22)$ indicated a direct primary 
responsibility for administration while $13.1 \%$ (8) specifically listed marketing and communications responsibilities and 5\% (3) specified strategic or long range planning responsibilities.

The educational attainment of the respondents was impressive with more than half having completed a master's level degree $(59.0 \%, 36)$ and one-fourth having completed a doctoral degree $(24.6 \%, 15)$. As would be expected given their positions, respondents' majors and academic concentrations were largely in the areas of theology/religion $(39.3 \%, 24)$, education/religious education $(30.1 \%, 22)$, and church ministry $(14.8 \%$, 9). While more than one-third of the respondents $(37.7 \%, 23)$ reported having majored or concentrated in a business or administration subject, only two reported majoring or concentrating in marketing or communications and one reported majoring or concentrating in business strategy.

\section{Profile Of Responding Organizations}

Approximately half of the churches in the study were located in suburban settings $(49.2 \%, 30)$ with another $41 \%$ (25) located in urban areas. The most common denomination was Baptist $(45.9 \%, 28)$; however, there were several denominations represented in the study including Methodist, Lutheran, Presbyterian, Evangelical Free as well as independent churches.

As expected given the sampling criteria, the average weekly attendance reported by the responding churches was 1,292. However, only $16 \%$ (10) of the respondents characterized attendance at these churches as "at the desired level"; all of the rest of the respondents $(83.6 \%, 51)$ characterized weekly attendance as being "below the desired level". This finding suggests that these organizations would be actively pursuing means and methods of attracting more attendees. Consequently, the appeal of strategic planning and marketing techniques should be relevant and the application of these practices by these churches would be expected.

\section{Activities \& Documents}

Of the eight marketing and planning activities listed on the survey (see Table 1), two were reportedly present in at least three-quarters of the responding churches: advertising $(86.9 \%, 53)$ and strategic planning $(75.4 \%$, 46). This finding is consistent with expectations borne out of the earlier reported finding that a vast majority of the participating churches were dissatisfied with their overall level of weekly attendance, since advertising and strategic planning are often viewed as means by which organizations can attract "new customers."

Table 1: Presence of Marketing and Planning Activities

\begin{tabular}{|c|c|}
\hline Activity & \% of Churches Reporting Existence (n) \\
\hline Advertising & $86.9 \%(53)$ \\
\hline Strategic Planning & $75.4 \%(46)$ \\
\hline Target Marketing & $52.5 \%(32)$ \\
\hline Self Audits & $34.4 \%(21)$ \\
\hline Marketing Planning & $29.5 \%(18)$ \\
\hline Market Research & $21.3 \%(13)$ \\
\hline Market Segmentation & $13.1 \%(8)$ \\
\hline Positioning & $11.5 \%(7)$ \\
\hline
\end{tabular}

The most common plans and statements present at the reporting churches were mission statements $(91.8 \%$, $56)$, vision statements $(70.5 \%, 43)$ and value, philosophy or doctrinal statements $(63.9 \%, 39)$. This would be expected given the large percentage of churches using strategic planning, Surprisingly, three churches that reported using strategic planning did not report having a written strategic plan.

As for the activities other than advertising or strategic planning listed in Table 1, there was much less reported presence even though many of those activities are intended to be employed in conjunction with advertising. 
For example, advertising is most effective when part of an overall marketing plan and directed to a specific audience. In addition, advertising is often used to differentiate the sponsor from competitors. However, only slightly more than half of the respondents reported the use of target marketing $(52.5 \%, 32), 29.5 \%$ (18) reported the presence of marketing planning, only 13\% (8) reported using market segmentation and $11.5 \%$ (7) reported using positioning even though all four of these (target marketing, marketing planning, market segmentation and positioning) should be in place in order to develop effective advertising.

An additional area of inconsistency was present in the results. While more than half of the responding churches reportedly use target marketing, only $13 \%$ (8) indicated the use of market segmentation. Yet, market segmentation is a precursor to target marketing. Furthermore, $82 \%$ (50) of the responding churches reportedly "view all residents in the local area as potential attendees." The magnitude of this statistic is also inconsistent with the practice of target marketing.

A viable explanation for the low percentage of responding churches reporting various activities is unfamiliarity with "technical" marketing terminology. To account for this possibility, the survey asked a series of questions concerning the practice of various activities using everyday language instead of marketing terms. Apparent unfamiliarity with the scope of concepts or with terminology appears to be the case for marketing research and positioning, as follows.

In the area of marketing research, approximately twenty percent of the responding churches $(21.3 \%, 13)$ reported its use directly while the actual practice of marketing research appears to be higher based on the finding that nearly thirty percent of the churches $(29.5 \%, 19)$ reported conducting research on attendee perceptions at least once every three years, a primary research activity. In addition, many of the churches appear to conduct secondary research, even if informally. Specifically, half of the responding churches $(50.8 \%, 30)$ reported knowing the size and growth rate of their target market, 54.1\% (33) monitor the actions of local churches, at least occasionally, and $73.8 \%$ (45) maintain a list of similar churches.

In terms of positioning, a marketing concept intended to assist organizations in differentiating themselves from competitors in the minds of consumers, differences between direct report of activity and actual practice also are evident. Specifically, while only $11.5 \%$ (7) of the responding churches reported engaging in positioning, nearly two-thirds $(62.3 \%, 38)$ reported that they operate under the assumption that they are different from other churches in the same denomination, a statement that is reflective of the basic definition of positioning. Further evidence of a practical understanding of positioning is present in additional results showing that $41.0 \%$ (25) of churches have a long-term commitment to their differentiating assumption (modifying it no more than once every 3 years or longer), $39.3 \%$ (24) of churches refer to their differentiating assumption in the development of advertising and promotions, and $23.0 \%$ (14) of the churches have written statements of how their church is different from other churches.

For some activities, such as marketing research and positioning, a misunderstanding of, or unfamiliarity with, terminology does appear to be the case. However, in other instances, such as with target marketing and market segmentation, an improper use of the marketing technique is apparent. None of this is surprising given that the academic and vocational backgrounds of the church leaders are heavily focused outside of the business area.

\section{LIMITATIONS AND FUTURE RESEARCH}

As with any study, the current investigation has some limitations that should be acknowledged before considering the conclusions that this research supports. First, the small sample size is a limitation; although the distribution and attributes of the responding churches is representative of the population being surveyed, the possibility of sampling error remains. Second, even though there were compelling reasons to limit the study to large churches, the lack of a cross-section with respect to size is another limitation. Third, neither actual nor perceived effectiveness of the marketing and planning activities included in the study were evaluated. Finally, the possibility of bias exists in that the person completing the survey may not have been the person in the church who is most familiar with the organization's marketing and planning activities. 
In order to further understand current practice and to address both the limitations of the current research as well as additional gaps in the literature, several streams of future research are needed. Specifically, while the current study does contribute to the need for quantitative assessment of current practice, additional studies are needed in the same vein that compare marketing theory to marketing implementation in a cross section of churches according to size as well as denomination and location. In addition, a complete study of the nature of the religious organization marketing industry in the United States is not available. For example, how many companies are serving the marketing needs of churches, what services are offered and what is the purpose of these companies? Finally, research is needed that investigates the effectiveness of various communication tools and the impact of the systematic utilization of marketing and planning on the realization of church goals in areas such as growth, member retention and satisfaction and church mission statement fulfillment.

\section{CONCLUSIONS AND RECOMMENDATIONS}

Based on the literature review, there continues to be disagreement between the business need and benefit of marketing the organization and mission of the church versus the concern about marketing religion. However, as both the current study and the literature review reveal, churches are using marketing and planning concepts. What is not clear is whether church leaders recognize that they are using marketing concepts. What is even less clear is whether church leaders realize they often are using them incorrectly. With this realization they will then be more open to seeking professional assistance. If church leaders persist in the incorrect application of marketing concepts, it is likely that churches will not achieve desired outcomes, such as increased levels of attendance. Unfortunately, this lack of results from misapplication of marketing and planning tools could easily lead to the incorrect conclusion that the tools themselves are ineffective and inappropriate for use in the church setting.

What is first needed, therefore, is a concerted effort to educate church leaders on the marketing planning process. These efforts will not only point to the potentially great benefits to be realized through the coordinated use of marketing and planning activities, but also will help overcome the misapplication and misunderstanding of activities such as market segmentation, target marketing, positioning and even marketing research. While efforts to integrate exposure to these tools into the formal education of church leaders would be ideal, this would not adequately address the issues at hand given that many leaders have completed their education and will likely continue to be held responsible for marketing and planning activities in their churches. Consequently, in addition to exposure through formal education, where church size and funding permit, church leaders need to avail themselves of the assistance and training offered by marketing and planning professionals by either engaging in their direct hire to be part of the church staff or entering into consulting relationships. Higher education institutions, particularly religiously oriented ones, offering organizational leadership programs are a excellent sources of both potential employees and consultants.

Marketing and planning activities consume valuable organizational resources, both financial and human, which are in limited supply. Therefore, regardless of the route taken, church leaders who engage in marketing and planning have a responsibility to ensure that these activities are undertaken in the most efficient and effective manner possible. The misapplication and misunderstanding of key concepts revealed in this research call for increased diligence on the part of church leaders in overseeing and executing these efforts.

\section{REFERENCES}

1. Barna, George (1988). Marketing the Church, Colorado Springs: Navpress.

2. Barrett, Patrick (1996). Religious ads lift the spirit, Marketing, 16.

3. Belsie, Laurent (1995, October 24). Churches Extend Outreach to World Wide Web, Christian Science Monitor, 87(23), p. 13.

4. $\quad$ Burger, Katrina (1997, May 5). JesusChrist.com, Forbes, 159, 76-80.

5. Coke, Karl (2004, May 18). Ministry or Marketing? Lessons for the Third Millennium, Ministry or Marketing.

6. Culliton, James W. (1959, Spring). A Marketing Analysis of Religion, Business Horizons, 2, 85-92. 
7. Cutler, Bob D. (1991). Religion and Marketing: Important Research Area or a Footnote in the Literature?, Journal of Professional Services Marketing, 8(1), 153-164.

8. Cutler, Bob D., \& Winans, William A. (1999). What Do Religion Scholars Say About Marketing? Perspectives from the Religion Literature, Journal of Professional Services Marketing, 18(2), 133-145.

9. Duin, Julia (2005, August 22). Religion helped workers speak up, The Washington Times. Retrieved October 20, 2005, from http://insider.washingtontimes.com/articles/normal.php?StoryID=20051020$121913-8742 \mathrm{r}$

10. Follis, John (2001, January 8). A heavenly client requires a leap of faith, Adweek (Eastern Edition), 42(2), 14.

11. Housewright, Ed (1995, March 13). Do Church ads work, or compromise Gospel?, Marketing News, 29(6), 22.

12. Jesus, CEO. (2005, December 24). The Economist, 3.

13. Kinsman, Matthew (2002, March 1). Spreading the Word, Promo, 1.

14. Marty, Martin E (1987, May). Sunday Mass and the Media, Across the Board, 24(5).

15. McDaniel, Stephen W (1986). Marketing Communication Techniques in a Church Setting: Views on Appropriateness, Journal of Professional Services Marketing, 1(4), 39-54.

16. Miller, Lisa (1998, February 24). Religious Advertising Converts, Moving Toward a Tougher Sell, The Wall St. Journal (Eastern Edition), p. 1.

17. Moncrief, William C., Lamb, Charles W., Jr., Hart, Sandra Hile (1986). Marketing the Church, Journal of Professional Services Marketing, 1(4), 55-63.

18. Parker, Suzi (2001, February 16). Dotcom Churches: Ministry or Marketing?, Christian Science Monitor, 93(58), p.2.

19. Quinn, Michelle L. (2001, October 22). Minimal marketing serves Mennonites, Marketing News, 35(22), p. 5-6.

20. Stuart, Devan (2001). Let There Be Awareness, Business Journal, 16(18), p.1.

21. Veenker, Jody (1999, July 12). God Speaks To Commuters, Christianity Today,43(8), 00095753.

22. Webb, Marion S., Joseph, W. Benoy, Schimmel, Kurt, Moberg, Christopher (1998). Church marketing: Strategies for retaining and attracting members, Journal of Professional Services Marketing, 17(2), p. 1-16.

23. Wellner, Alison Stein (2001, June). Oh come all ye faithful, American Demographics, 23(6), p. 50-55.

24. Wrenn, Bruce (1993). The Role of Marketing in Religious Organizations, Journal of Professional Services Marketing, 8(2), p. 237-249.

25. Wrenn, Bruce (1994, Summer). Can (Should) Religion Be Marketed?, Quarterly Review 14, p.117-134. 